\title{
Temperature reconstruction (1750-2008) from Dahurian larch tree-rings in an area subject to permafrost in Inner Mongolia, Northeast China
}

\author{
Xianliang Zhang ${ }^{1,2}$, Xingyuan $\mathrm{He}^{1}$, Jinbao $\mathrm{Li}^{3}$, Nicole Davi ${ }^{3}$, Zhenju Chen ${ }^{1, *}$, \\ Mingxing $\mathrm{Cui}^{1,2}$, Wei Chen ${ }^{1}$, $\mathrm{Na} \mathrm{Li}^{1}$
}

\author{
${ }^{1}$ State Key Laboratory of Forest and Soil Ecology, Institute of Applied Ecology, Chinese Academy of Sciences, \\ Shenyang 110164, PR China \\ ${ }^{2}$ Graduate University of Chinese Academy of Sciences, 19 Yuquan Road, Beijing 10049, PR China \\ ${ }^{3}$ Tree-Ring Laboratory, Lamont-Doherty Earth Observatory, Columbia University, Palisades, New York 10964, USA
}

\begin{abstract}
May-September temperatures were reconstructed for the past $250 \mathrm{yr}$ based on Dahurian larch Larix gmelinii Rupr. growing in permafrost region of Northeast China. The reconstruction accounts for $39.3 \%$ of the actual temperature variance over the period 1958-2008. The reconstruction captured 3 relatively cold periods in 1847-1852, 1861-1866 and 1935-1941; 2 relatively warm periods in 1874-1879 and 2001-2008; and a persistent warming trend since the mid-20th century. The longterm changes in temperature documented here correspond well with regional temperature change from observational records, other global and regional proxy-based temperature reconstructions, and documented changes in regional permafrost. Thus, valuable information might be preserved in our reconstruction about local- to regional-scale climatic variation during the past 2.5 centuries.
\end{abstract}

KEY WORDS: Tree-ring width · Temperature reconstruction · Dahurian larch · Permafrost change · Climatic variation

Resale or republication not permitted without written consent of the publisher

\section{INTRODUCTION}

The trend of increasing terrestrial surface air temperature has been observed over much of the world during the 20th century (Mann et al. 1998, IPCC 2007). This increase has, and will likely continue to have, great influences on terrestrial and aquatic ecosystems (Melillo et al. 1993, Cao \& Woodward 1998, Shaver et al. 2000). Understanding the potential effects of such temperature change requires a detailed understanding of long-term trends and variation in regional temperatures over the past several hundred years or more (Fritts 1976, Esper et al. 2002, Zhang et al. 2003). Single site or regional climate models based on tree rings and other proxies simulate the history of past climate variability at the site or in the region. For instance, the average temperature of the northern hemisphere was reconstructed based on tree rings and other proxies (Mann et al. 1998), and the reconstruction reflects the basic trend observed in temperature variation on a global scale. Most instrumental records from the highlatitude regions of China, however, are only available after the 1950s. Consequently, reconstructing the temperature of the past several hundred years or more is critical for placing future temperature predictions and possible changes within a long-term context.

Tree rings as an annually resolved, exactly dated, and continuous proxy record have been widely used to reconstruct past climate (Fritts \& Lough 1985, Cook et al. 2000, Jacoby et al. 2003, Briffa et al. 2004). Treering records have been used to reconstruct past precipitation and temperature for central China (Hughes et al. 1994, Liu \& Shao 2000, Liu et al. 2009a), western China (Zhang et al. 2003, Liu et al. 2005, 2008, 2009b, Yang et al. 2009), southern China (Fan et al. 2008, 2009), and eastern China (Liang et al. 2001). In Northeast China, however, there are only a few documented tree-ring based temperature reconstructions available 
for the southern Northeast regions (Shao \& Wu 1997 , Zhu et al. 2009), and none are available for the permafrost-dominated northern regions.

Furthermore, the rapid increase in temperature in high-latitude areas of Northeast China (Qian \& Lin 2004) suggests that the ecosystems of this region will potentially undergo large impacts arising from climate change. The permafrost in this region $\left(0.38 \times 10^{6} \mathrm{~km}^{2}\right.$, accounts for $17.67 \%$ of the total area of permafrost in China; Jin et al. 2000) is quite sensitive to changes in temperature (Kääb et al. 2007). Incremental changes in temperature are a well documented cause of permafrost degradation during the 20th century (Zhou et al. 2003, Osterkamp 2005, Harris et al. 2009). Changes in permafrost stemming from continually rising temperatures will likely necessitate alternatives in building and road engineering, construction practices, water resources, and forest products (Jin et al. 2000, Zhou et al. 2002, Yang et al. 2010). Moreover, it can cause severe environmental changes for tree growth. Thus, in order to contextualize recent and potential temperature changes in the future, it is necessary to produce a long-term temperature reconstruction for this region using tree-ring records. Accordingly the major goals of the present study are: (1) to determine the climate-growth relationships of local trees relative to biophysically important variables (temperature, precipitation); (2) to investigate the linkages between regional temperature change and other records documenting regional to global-scale changes in temperature; and (3) to assess the influences of permafrost degradation induced by past temperature variations on radial growth.

\section{MATERIALS AND METHODS}

\subsection{Study area and sampling sites}

The study area is located in the western Great Xing'an Mountain, a dividing zone of dry/wet and cold/ warm climate in northeastern China and a typical monsoon boundary zone (continental monsoon climate) (Fig. 1). The sampling site $\left(51^{\circ} 03^{\prime} 15^{\prime \prime}-52^{\circ} 08^{\prime} 08^{\prime \prime} \mathrm{N}\right.$, $120^{\circ} 00^{\prime} 20^{\prime \prime}-121^{\circ} 19^{\prime} 21^{\prime \prime}$ E; Fig. 1) is located in the permafrost region (Jin et al. 2000, Sun et al. 2007). The climate of this region is characterized by low temperature and moisture levels (Fig. 2). The annual mean temperature is ca. $-15^{\circ} \mathrm{C}$, and the annual precipitation is ca. $450 \mathrm{~mm}$. The mean temperature in January, the coldest month of the year, is ca. $-25^{\circ} \mathrm{C}$ to $-28^{\circ} \mathrm{C}$, while the mean temperature in July, the warmest month of the year, is ca. 18 to $20^{\circ} \mathrm{C}$. The permafrost is geographically continuous in this region due to the low annual temperature and other reasons (Sun et al. 2007). As a

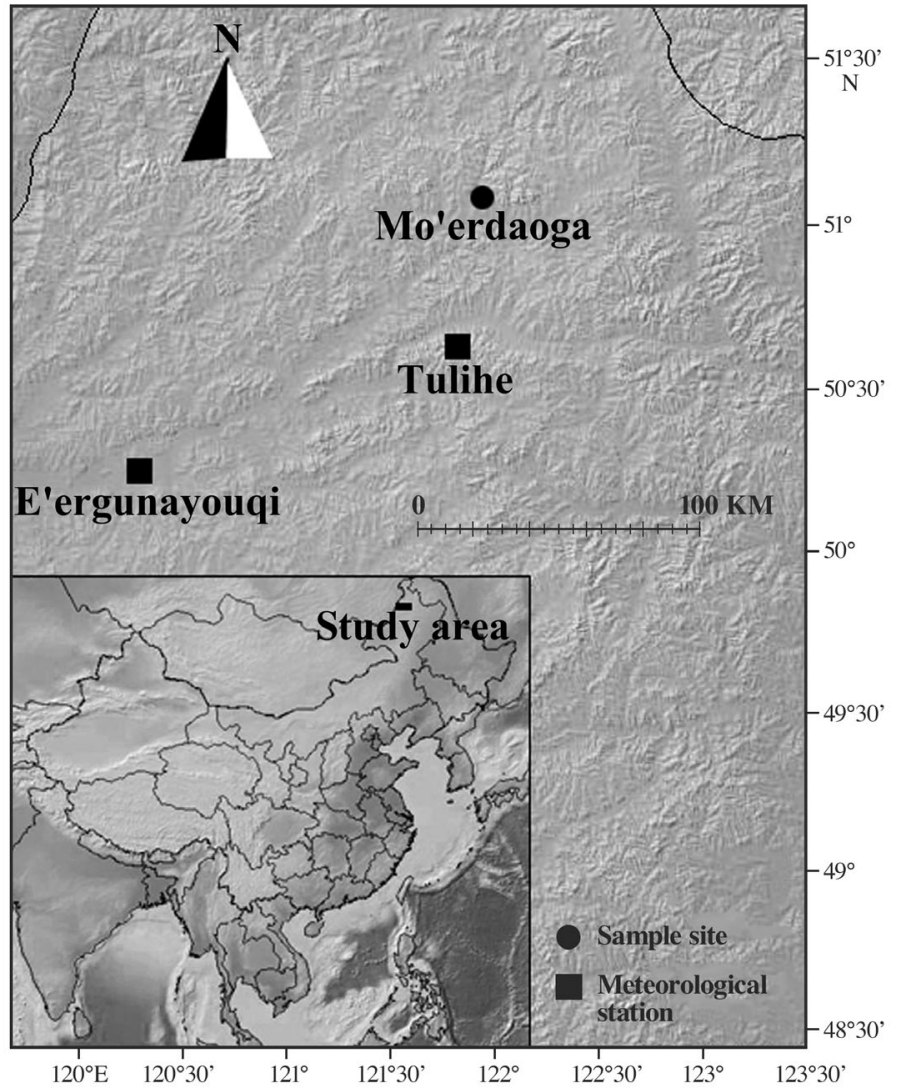

Fig. 1. Sampling site and locations of meteorological stations

result, tree growth is deeply affected by frozen soil. Dahurian larch Larix gmelinii Rupr., the dominant species in this region, has adapted to the tough permafrost environment, but grows slowly due to limitations imposed by the frozen soil.

\subsection{Tree-ring sampling and chronology development}

Fifty-two cores were sampled from 25 living Dahurian larch trees ( 2 to 3 cores tree ${ }^{-1}$ ) at breast height using an increment borer in a forest relatively undisturbed by human activities (e.g. felling, roads). Cores were dried, mounted, and fine-sanded until every ring was clearly visible under a binocular microscope. All samples were then visually cross-dated, and the ring widths were measured to the nearest $0.001 \mathrm{~mm}$ by the LINTAB5 measuring system. The program COFECHA (Holmes 1983) was used to verify the results of visual cross-dating. During this process some series were discarded because they had a poor relationship with the master series. The final chronology was developed from 46 cores collected from 23 trees. The time span of the master series was $294 \mathrm{yr}$ (1715-2008), series inter-correlation was 0.487, and mean sensitivity was 0.245 (Table 1). 


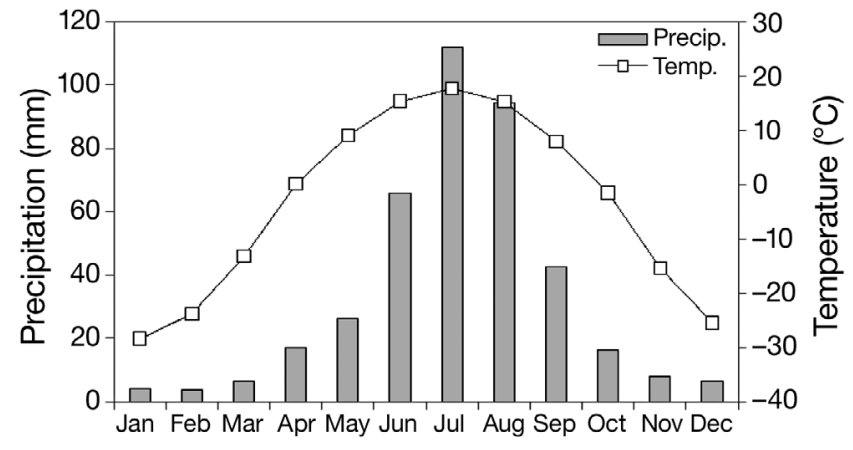

Fig. 2. Mean temperature (Temp.) and precipitation (Precip.) at the 2 meteorological stations

Table 1. Statistics for the standard (STD) chronology. SSS: subsample signal strength

\begin{tabular}{|lc|}
\hline Parameter & STD \\
\hline Mean sensitivity & 0.139 \\
Standard deviation & 0.221 \\
First-order autocorrelation & 0.656 \\
Mean correlation within a tree & 0.693 \\
Variance in the first eigenvector $(\%)$ & 34.4 \\
Expressed population signal & 0.91 \\
First year where SSS > 0.75 (number of trees) & $1723(8)$ \\
\hline
\end{tabular}

Detrending and standardization of the raw ringwidth series was performed using the ARSTAN software (Cook \& Holmes 1986). The raw series were detrended to remove the influences of age, stand dynamics, and other factors unrelated to climate. In order to retain as much low-frequency signal as possible, individual ring-width series were conservatively detrended using either a linear or negative exponential function. However, if an adequate fit could not be obtained using either of these methods, a cubic spline function with a frequency cut-off equal to two-thirds of the series length was used (8 cores). After detrending, the tree ring series still show autocorrelation related to the previous year's growth, so an autoregressive model was used to remove the influences of the past year. Then, the mean index was calculated using the biweight robust mean method. Consequently, the standard (STD), residual and arstan chronologies were developed. Given that the STD chronology (Fig. 3) preserves more low-frequency signal than other versions of chronologies (Cook \& Kairiukstis 1990), the STD chronology was used in the following analysis.

\subsection{Meteorological data}

The meteorological records were obtained from the China Meteorological Data Sharing Service System (http://cdc.cma.gov.cn/). The longest and most continuous meteorological records from 2 proximate stations were selected to model the regional climate signals in tree rings: Tulihe $\left(50^{\circ} 29^{\prime} \mathrm{N}, 121^{\circ} 41^{\prime} \mathrm{E}\right.$, $732.6 \mathrm{~m}$ above sea level [a.s.l.]) and $\mathrm{E}^{\prime}$ ergunayouqi $\left(50^{\circ} 15^{\prime} \mathrm{N}, 120^{\circ} 11^{\prime} \mathrm{E}, 581.4 \mathrm{~m}\right.$ a.s.l.) meteorological stations (Fig. 1). The meteorological stations are located at approximately the same altitude as the tree-ring sampling site (Fig. 1). The distances between our sampling site and the 2 meteorological stations are ca. $110 \mathrm{~km}$. Although the distance between the 2 meteorological stations is relatively far (ca. $100 \mathrm{~km}$ ), significant correlations $(\mathrm{p}<0.01)$ were found between all records over the period (1958-2008, e.g. monthly precipitation: $\mathrm{r}_{\text {mean }}=0.615, \mathrm{p}<0.001$; monthly mean temperature: $\left.\mathrm{r}_{\text {mean }}=0.931, \mathrm{p}<0.001\right)$. Averaging meteorological records from different stations decreases small-scale noise or stochastic components and improves statistical relationships between tree-ring and meteorological data (Blasing et al. 1981, Pederson et al. 2001). Thus, the regional mean meteorological data were produced by averaging monthly records of the 2 proximate stations over the interval 1958-2008.

The regional gridded temperature data $\left(120-121^{\circ} \mathrm{N}\right.$, $50-51^{\circ} \mathrm{E}$ ) of CRU (Climate Reach Unit, UK) TS 3.0 (Mitchell \& Jones 2005), the mean temperature of the northern hemisphere (1850-2008, HadCRUT3), and the thaw depth $\left(50-53^{\circ} \mathrm{N}, 120-123^{\circ} \mathrm{E}\right)$ data on permafrost were downloaded from KNMI Climate Explorer (www.knmi.nl). The climate-growth relationship between the STD chronology and climate factors (monthly mean temperature and total precipitation) was investigated by simple Pearson correlation analysis. Spatial correlation analysis between the reconstruction and regional temperature was performed using KNMI Climate Explorer.

\section{RESULTS}

\subsection{Regional climate variability}

During the past 51 yr (1958-2008), significant temperature and rainfall changes were observed in the instrumental record. Annual mean temperature has increased significantly $\left(0.4^{\circ} \mathrm{C}\right.$ decade $\left.^{-1}, \mathrm{p}<0.01\right)$, and annual precipitation has decreased slightly $\left(0.7 \mathrm{~mm}\right.$ decade $\left.^{-1}\right)$. Summer and winter mean temperatures have increased significantly $\left(0.44^{\circ} \mathrm{C}\right.$ decade $^{-1}$, $\mathrm{p}<0.01$ and $0.3^{\circ} \mathrm{C}$ decade $^{-1}, \mathrm{p}<0.01$, respectively), indicating that temperature during the growth season (May-September) of Dahurian larch has experienced significant change $(p<0.01)$. Growing degree-days $>10^{\circ} \mathrm{C}$ (which determines the growing days of vegetation), which mainly occur May-September, have in- 

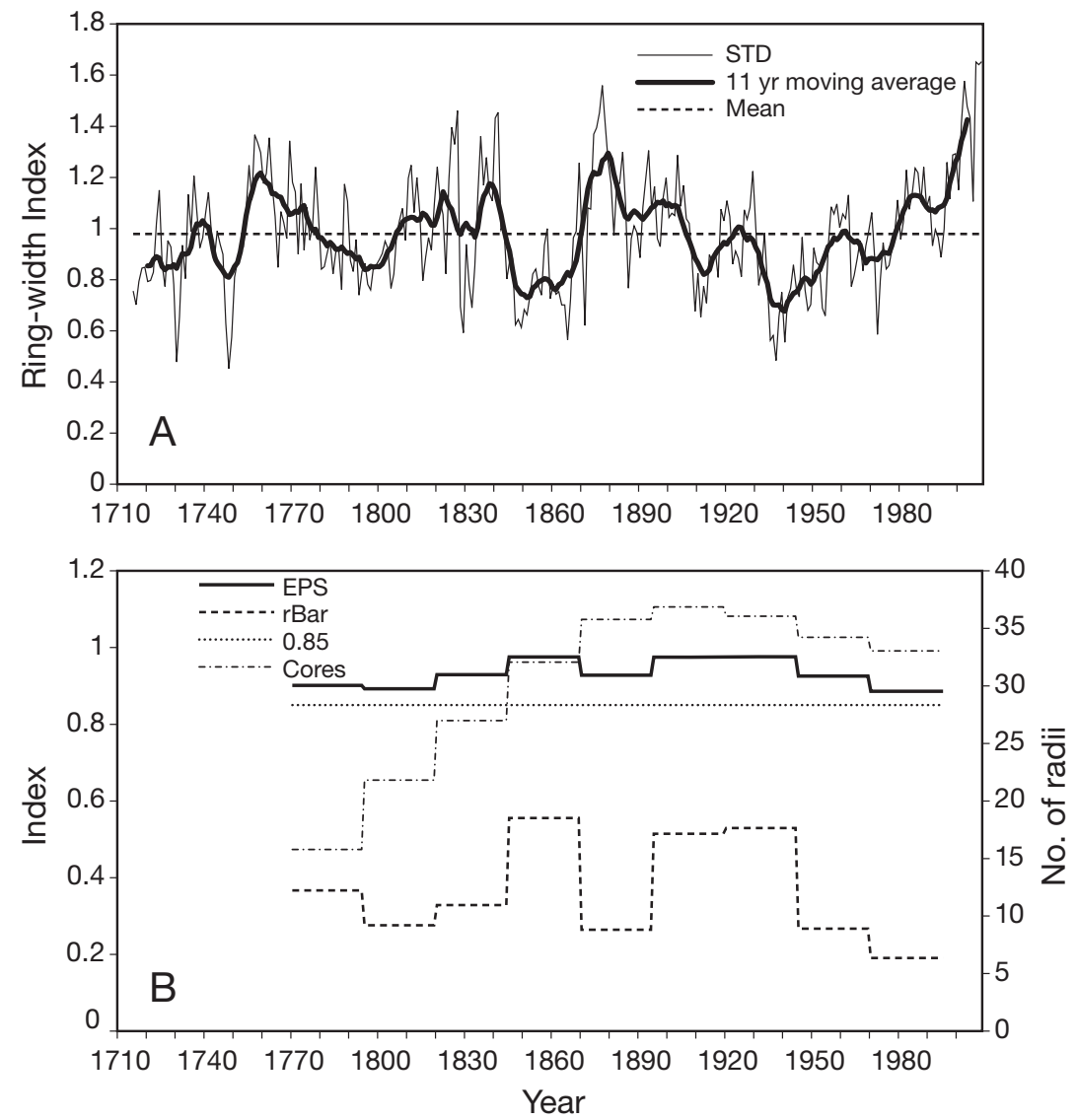

Fig. 3. (A) Standard (STD) chronology for 1715-2008, its mean, and its 11 yr moving average. (B) Mean interseries correlation (rBar), expressed population signal (EPS), and sample depth are based on a window length of $20 \mathrm{yr}$ with a $10 \mathrm{yr}$ overlap. An EPS level of 0.85 or above is generally viewed as an acceptable level

suggesting a strong influence of climate on tree growth during the previous year. The expressed population signal statistic (EPS; Wigley et al. 1984) is a criterion to evaluate the reliability of a chronology. The mean EPS was 0.93 (range: 0.89 to 0.98 ), and the mean rBar was 0.37 (range: 0.19 to 0.56 ), calculated for $20 \mathrm{yr}$ intervals with $10 \mathrm{yr}$ overlaps. Based on the EPS > 0.85 criterion, the chronology had adequate signal strength after 1750, which is the first year of our reconstruction. These results indicated that our chronology was suitable for dendroclimatological studies.

\subsection{Climate-growth relationships}

The relationships between the STD chronology and climatic variables (monthly mean temperature and precipitation) were calculated from the previous September to current October 1958-2008 using correlation analysis. Results (Fig. 4) show that both temperature and precipitation influence tree growth at this high-altitude of Northeast China, but that temperature is the major limiting climatic factor. The influence of temperature is especially strong in May-September $(p<0.01)$,

creased by $0.326^{\circ} \mathrm{C}$ decade $^{-1}(\mathrm{p}<0.01)$. MaySeptember rainfall, accounting for $84.7 \%$ of the yearly total precipitation, has decreased by $11.6 \mathrm{~mm}$ $\operatorname{decade}^{-1}$ ( $\left.\mathrm{p}<0.01\right)$. May-September mean temperatures have increased by $0.43^{\circ} \mathrm{C} \operatorname{decade}^{-1}(\mathrm{p}<0.01)$. These results demonstrate that the regional climate has already changed significantly in the last half-century, especially during the growing season (May-September) of Dahurian larch.

\subsection{Chronology statistics}

The tree-ring width chronology of Dahurian larch spanned 294 yr (1715-2008). All the statistics of the chronology contained a strong common signal. Mean sensitivity, a measure that indicates the difference between adjacent rings, was 0.138. First-order autocorrelation was 0.67,

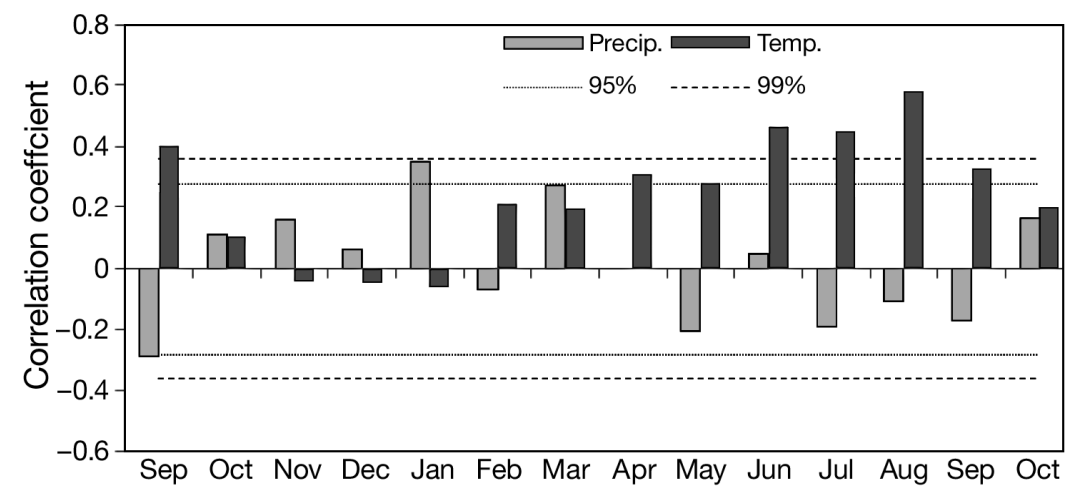

Fig. 4. Correlation coefficients between climatic factors (temperature, Temp. and precipitation, Precip.) and standard chronology 
Different combinations of seasonal months were tested, and the best relationship was found between ring width (or growth) and May-September temperature (hereafter MST), with $\mathrm{r}=0.627$ ( $\mathrm{p}<0.01)$. Therefore, the mean growing season temperature (MaySep) was reconstructed.

\subsection{Temperature reconstruction}

Based on the above climate-growth analysis, a simple linear regression model was built by calibrating tree-ring width from the STD chronology against average MST. The regression model $(\mathrm{MST}=10.568+$ 2.307STD) cross-validated well (Table 2) and was statistically significant $(F=31.75, \mathrm{p}<0.001)$. The final temperature reconstruction was well correlated with observational data ( $r=0.627, p<0.01$; Fig. 5), and explained $39.3 \%$ of the total variance in the period 1958-2008; after adjusting for the loss of degrees of freedom, it still explained $38.1 \%$ of the total temperature variance (Table 2).

We used the leave-one-out cross-validation methods to check the reliability and stability of the regression model, as other validation methods did not fit due to

Table 2. Statistical characteristics of calibration and verification of leave-one-out validation (mean and range in parentheses). $r$ : correlation coefficient; $r^{2}$ : square of $r$, representation of total variance; $r^{2}$ adj: square of $r$ after adjusting the degree loss

\begin{tabular}{|lcc|}
\hline Statistical item & $\begin{array}{c}\text { Calibration } \\
(1957-2008)\end{array}$ & $\begin{array}{c}\text { Verification } \\
(1957-2008)\end{array}$ \\
\hline $\mathrm{r}$ & 0.627 & $0.627(0.58-0.67)$ \\
$\mathrm{r}^{2}$ & 0.393 & $0.393(0.33-0.45)$ \\
$\mathrm{r}^{2}$ adj & 0.381 & $0.381(0.32-0.44)$ \\
$F$ & 31.75 & $31.174(23.92-38.97)$ \\
$\mathrm{p}$ & $<0.001$ & $<0.001$ \\
\hline
\end{tabular}

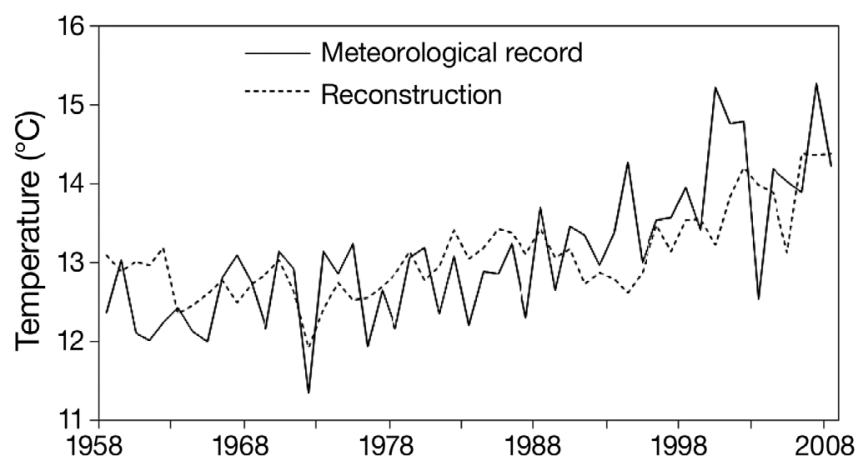

Fig. 5. Comparison of mean temperature reconstruction and mean temperature of meteorological records (1958-2008) for the period May-September the shortness of the meteorological record (Liu et al. 2009a, Zhu et al. 2009). In the leave-one-out cross-validation, each value was removed once from observed temperature series and predicted by a model generated from the remaining data (Michaelsen 1987). The results of the leave-one-out cross-validation (Table 2) show that there were no significant changes in correlation coefficients after the $1 \mathrm{yr}$ value was removed from the whole time period, and the average correlation coefficient is $0.574(p<0.01)$ between leave-one-out reconstruction series and the instrumental record, which indicates a high-quality reconstruction.

The mean temperature for May through September was reconstructed for the period since 1750 (Fig. 6). A value of $+1 \sigma$ above the mean ( $\sigma$ is the standard deviation $=0.877^{\circ} \mathrm{C}$ ) designates an extremely warm year, and an extremely cold year has a value of $-1 \sigma$ below the mean (Fig. 6). There were 35 extremely cold years $(13.5 \%$ of total years) and 42 extremely warm years $(16.2 \%$ of total years) in the whole reconstruction period. Extremely cold periods lasting for $>3$ yr were 1847-1852, 1861-1866, and 1935-1941, and extremely warm periods were 1874-1879 and 2001-2008. The coldest year prior to the instrument record was 1937 , with $11.68^{\circ} \mathrm{C}$, while the warmest year was 1877 , with $14.17^{\circ} \mathrm{C}$. The warmest decades were $1870-1880$ and 1998-2008, and the coldest decades were 1850-1860 and 1935-1945. After smoothing with an 11 yr moving average, cold periods occurred in 1844-1857 and 1930-1949, while warm periods occurred in 17531764, 1869-1886, and 1993-2008.

Spatial correlations of instrumental and reconstructed temperatures with regional temperatures were also performed (Fig. 7). The results show significant correlations with gridded climatic variables on a regional scale, indicating that our reconstruction represents climatic variations for a large area surrounding our sampling site.

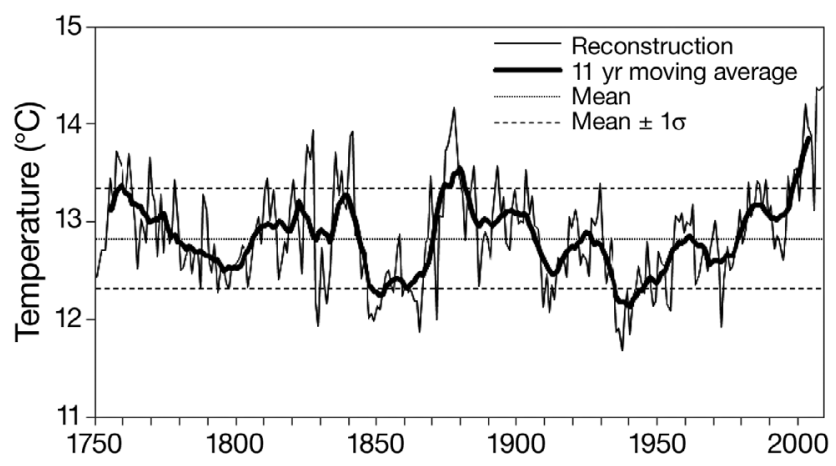

Fig. 6. Mean, mean $\pm 1 \sigma$, and 11 yr moving average of May-September temperature reconstruction series 


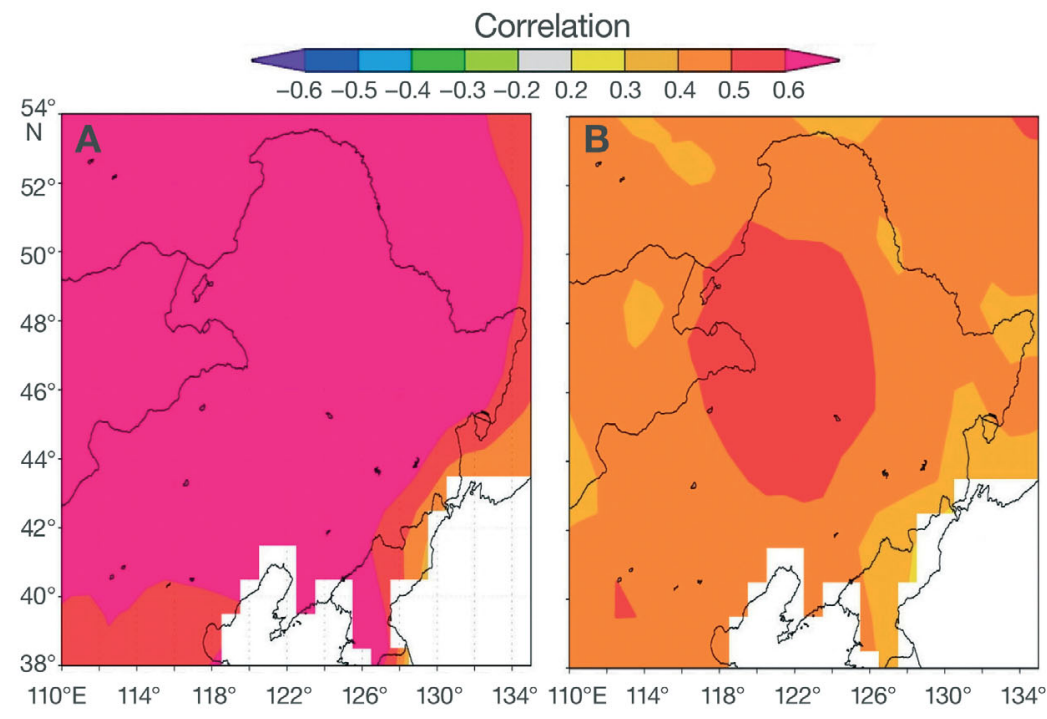

Fig. 7. Spatial correlation of (A) instrumental and (B) reconstructed MaySeptember temperatures with regional gridded May-September temperatures during the period 1958-2008

\section{DISCUSSION}

\subsection{Climate-growth response}

Although the total annual precipitation has a downward trend in recent years, precipitation was not the main limiting factor to radial growth as only the previous September and current January rainfall show significant correlations. More rainfall in the previous September is always accompanied by low illumination. Photosynthesis rate would be limited due to low illumination during the growth season, so light is a more important limiting factor than precipitation when precipitation is sufficient. Therefore, more rainfall in the previous September has a negative effect on radial growth. In contrast, January rainfall has a positive effect on radial growth. The main water source in January is snow. Melt-water could increase water availability, which is critical to tree radial growth when the trees start sprouting. Therefore, rainfall in January is a positive variable for tree radial growth. There are no significant correlations between precipitation and tree rings during the other months of the growing season. This may be due to the low evaporation rates and sufficient precipitation during the rest of the year.

Radial growth in trees in this region was mainly controlled by May-September temperatures. Positive correlations between tree rings and summer temperatures in the current year were also observed in other regions of northeastern China (Shao \& Wu 1997, Wang et al. 2005, Chen et al. 2008). The sampling site in the present study is located at a high latitude characterized by low temperatures. The average temperature in July, the warmest month of the year, was not very high (15.5$19.8^{\circ} \mathrm{C}$ ). Low temperatures during the growing period (May-September) would greatly limit the photosynthesis process and physiological activities of trees, causing temperature to be a major limiting factor of tree radial growth in this region.

\subsection{Comparison with other regional temperature records and hemispheric temperature reconstructions}

Regional temperature variations have been well captured by our reconstruction. Hence, our reconstruction provides a valuable profile of past climatic change in this region. Spatially, at the regional-scale, both the reconstruction and instrumental records have significant correlations with regional gridded temperatures $\left(38-55^{\circ} \mathrm{N}, 112-130^{\circ} \mathrm{E}\right)$ during the period $1958-2008$ (Fig. 7), suggesting that the reconstruction preserves reliable information about regional climate variability. On a global scale, significant correlations $(\mathrm{r}=0.311$, $p<0.01$ ) were also found between the reconstruction and the mean temperatures (May-September) of the northern hemisphere data (HadCRUT3) during the period 1850-2008. Temporally, the reconstruction has a very close relationship with the available regional $1^{\circ} \times 1^{\circ}$ gridded data (CRU TS 3.0) at low (annual data: $\mathrm{p}<0.05$ ) and high frequencies from 1901 to 2006 (the first difference: $p<0.01$, which shows that the reconstruction possesses certain climate signals on both high and low frequencies in this region. The correlation coefficient is as high as 0.513 between the reconstruction and MaySeptember mean temperatures of the gridded data during the period 1958-2006.

In addition, our reconstructed warm/cold periods are generally consistent with other documented data in northeastern China, such as the cold periods of $1874-$ 1879 and 1935-1941 and the warm period of 18741879 in the Changbai Mountains (February-April temperatures) (Shao \& Wu 1997). Interestingly, our 2 estimated extremely cold periods in 1847-1852 and 18611866, the extremely warm period in 1753-1764, and an upward trend after 1950 were found in the tree-ringbased temperature reconstruction with Dahurian larch (Sano et al. 2009), and the cold period of 1860-1880 in our reconstruction was coincident with summer temperature reconstruction (Solomina et al. 2007) in Kamchatka. Furthermore, both studies have similar varia- 
tion patterns to our reconstruction over the past 3 centuries based on smoothed 11 yr moving averages.

\subsection{Relationships to documented changes across permafrost ecosystems}

The permafrost is widely distributed in this region, and it is sensitive to increasing temperatures (Jin et al. 2000, Harris et al. 2003, Osterkamp 2005). It is well known that increasing temperatures may cause great changes in the regional ecosystem, particularly in the permafrost system; our reconstruction has significant correlation $(\mathrm{p}<0.01$ ) with the regional permafrost thaw depth $\left(50-53^{\circ} \mathrm{N}, 120-123^{\circ} \mathrm{E}\right)$ from 1901 to 2001 (Fig. 8), indicating that increasing temperatures have aggravated the degrading of permafrost. If temperatures increase rapidly, the degradation of permafrost will lead to great environmental, ecological, and other problems (Jin et al. 2000). The trend of degrading permafrost could especially affect tree radial growth in the transition zone. In the region where the frozen soil is shallow, although there is enough precipitation, tree roots cannot absorb sufficient water from the frozen soil for physiological processes, so the trees are still slender at a mature age. Therefore, it is expected that the growth condition of these trees would be improved as permafrost becomes more degraded. Furthermore, similar to the relationship with increasing mean temperatures, an increase in growing degree-days $>10^{\circ} \mathrm{C}$ has a significant positive relationship with chronology $(\mathrm{r}=0.517, \mathrm{p}<0.001, \mathrm{n}=51)$. The increase of both mean temperature and growing degree-days will accelerate local tree growth and increase tree growth days. Therefore, climate warming would accelerate tree radial growth in temperature-limited areas. The degradation of permafrost caused by temperature increases may be positive for tree radial growth. How- ever, samples taken from the non-permafrost area (Zhang et al. 2010) had a negative relationship with chronology. All in all, the coupled effects of temperature increase would be beneficial to tree radial growth over time. However, our results (positive correlations between tree growth and elevated temperatures) do not agree with the findings of other authors that the Duhalian larch will retreat or be replaced by other species (Leng et al. 2008) and may suffer from irreversible changes in the forest ecosystem due to global warming (Zhou et al. 2002, 2003).

\section{CONCLUSIONS}

In the present study, we developed a ring-width chronology spanning 1715-2008 AD using Dahurian larch from a permafrost region in northern Inner Mongolia, Northeast China. The chronology was significantly and positively correlated to mean temperatures of May-September. Based on this relationship, temperatures from 1750-2008 were reconstructed for this region. This reconstruction accounts for $39.3 \%$ of the total temperature variance in the period 1958-2008, and provides valuable climatic information for the past 258 yr. The reconstruction captured regional temperature trends such as those seen in the northern hemisphere, CRU TS 3.0 gridded data, and regional permafrost thaw depth. All of these results indicate that this reconstruction is reliable and captures valuable information about regional cold and warm variability, and also large-scale temperature change.

Acknowledgements. This work was funded by the National Natural Science Foundation of China Projects 41071035, 30600093, and 31000222 and the China Special Research Program for Public-Welfare Forestry (Grant No. 200804001).

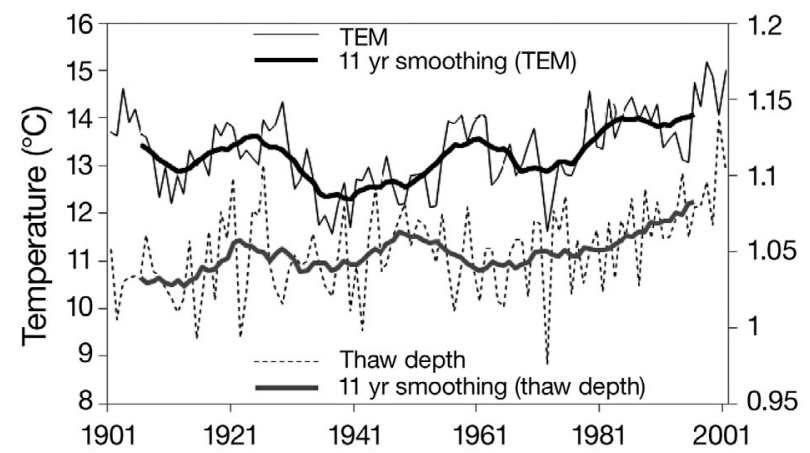

Fig. 8. Annual variations and trends (smoothed by 11 yr average) of thaw depth of permafrost and reconstructed temperatures (TEM). Thaw depth $\left(50-53^{\circ} \mathrm{N}, 120-123^{\circ} \mathrm{E}\right)$ data for permafrost downloaded from KNMI Climate Explorer (www.knmi.nl)

\section{LITERATURE CITED}

Blasing TJ, Duvick DN, West DC (1981) Dendroclimatic calibration and verification using regionally averaged and single station precipitation data. Tree-Ring Bull 41: $37-43$

Briffa KR, Osborn TJ, Schweingruber FH (2004) Large-scale temperature inferences from tree rings: a review. Global Planet Change 40:11-26

Cao MK, Woodward F (1998) Dynamic responses of terrestrial ecosystem carbon cycling to global climate change. Nature 393:249-252

Chen ZJ, Sun Y, He XY, Chen W and others (2008) Chinese pine tree-ring width chronologies from Qianshan Mountains and its relation to climatic variations. Front For China 3:381-392

Cook ER, Holmes RL (1986) Users manual for the program ARSTAN. Laboratory of Tree-Ring Research, University of Arizona, Tucson, AZ 
Cook ER, Kairiukstis LA (eds) (1990) Methods of dendrochronology. Kluver, Dordrecht

Cook ER, Meko DM, Stahle DW, Cleaveland MK (1999) Drought reconstructions for the continental United States. J Clim 12:1145-1162

Cook ER, Buckley BM, D'Arrigo RD, Peterson MJ (2000) Warm-season temperatures since $1600 \mathrm{BC}$ reconstructed from Tasmanian tree rings and their relationship to largescale sea surface temperature anomalies. Clim Dyn 16: 79-91

Esper J, Cook ER, Schweigruber FH (2002) Low-frequency signals in long tree-ring chronologies for reconstructing past temperature variability. Sciences (New York) 295: $2250-2253$

Fan ZX, Bräuning A, Cao KF (2008) Annual temperature reconstruction in the central Hengduan Mountains, China, as deduced from tree rings. Dendrochronologia 26: 97-107

Fan ZX, Bräuning A, Yang B, Cao KF (2009) Tree ring density-based summer temperature reconstruction for the central Hengduan Mountains in southern China. Global Planet Change 65:1-11

Fritts HC (1976) Tree rings and climate. Academic Press, London

Fritts HC, Lough JM (1985) An estimate of average annual temperature variations for North America, 1602 to 1961. Clim Change 7:203-224

Harris C, Muhll DV, Isaksen K (2003) Warming permafrost in European mountains. Global Planet Change 39:215-225

> Harris C, Arenson LU, Christiansen HH, Etzelmüller B (2009) Permafrost and climate in Europe: monitoring and modelling thermal, geomorphological and geotechnical responses. Earth Sci Rev 92:117-171

Holmes RL (1983) Computer-assisted quality control in treering dating and measurement. Tree-Ring Bull 43:69-78

- Hughes MK, Wu XD, Shao XM, Cao KF (1994) A preliminary reconstruction of rainfall in North-Central China since A.D. 1600 from tree-ring density and width. Quat Res 42:88-99

IPCC (Intergovernmental Panel on Climate Change) (2007) Climate change 2007: synthesis report. Cambridge University Press, Cambridge

Jacoby G, Pederson N, D'Arrigo RD (2003) Temperature and precipitation in Mongolia based on dendroclimatic investigations. Chin Sci Bull 48:1474-1479

> Jin HJ, Li SX, Cheng GD, Garfin GM (2000) Permafrost and climatic change in China. Global Planet Change 26: 387-404

Kääb A, Chiarle M, Raup B (2007) Climate change impacts on mountain glaciers and permafrost. Global Planet Change 56:vii-ix

Leng WF, He HS, Bu RC, Dai LM, Hu YM, Wang XG (2008) Predicting the distributions of suitable habitat for three larch species under climate warming in northeastern China. For Ecol Manag 254:420-428

Liang EY, Shao XM, Hu YX, Lin JX (2001) Dendroclimatic evaluation of climate-growth relationships of Meyer spruce (Picea meyeri) on a sandy substrate in semi-arid grassland, north China. Trees (Berl) 15:230-235

Liang EY, Shao XM, Qin NS (2008) Tree-ring based summer temperature reconstruction for the source region of the Yangtze River on the Tibetan Plateau. Global Planet Change 61:313-320

Liu HB, Shao XM (2000) Reconstruction of early spring temperature Zhennan from 1775 using tree ring chronology. Acta Meteorol Sin 58:421-432 (in Chinese)

Liu XH, Qin DH, Shao XM, Chen T, Ren JW (2005) Tempera- ture variations recovered from tree-rings in the middle Qilian Mountain over the last millennium. Sci China Ser D: Earth Sci 48:521-529

> Liu Y, Bao G, Song HM, Cai QF, Sun JY (2009a) Precipitation reconstruction from Hailar pine (Pinus sylvestris var. mongolica) tree rings in the Hailar region, Inner Mongolia, China back to 1865 AD. Palaeogeogr Palaeoclimatol Palaeoecol 282:81-87

- Liu Y, An ZS, Linderholm HW, Chen DL and others (2009b) Annual temperature during the last 2485 years in the mideastern Tibetan Plateau inferred from tree rings. Sci China Ser D Earth Sci 52:348-359

> Mann ME, Bradley RS, Hughes MK (1998) Global-scale temperature patterns and climate forcing over the past six centuries. Nature 392:779-788

Melillo JM, McGuire AD, Kicklighter DW, More B III, Vorosmarty CJ, Schloss AL (1993) Global climate change and terrestrial net primary production. Nature 363:234-239

Michaelsen J (1987) Cross validation in statistical climate forecast models. J Clim Appl Meteorol 26:1589-1600

> Mitchell TD, Jones PD (2005) An improved method of constructing a database of monthly climate observations and associated high-resolution grids. Int $\mathrm{J}$ Climatol 25: 693-712

Osterkamp TE (2005) The recent warming of permafrost in Alaska. Global Planet Change 49:187-202

> Pederson N, Jacoby GC, D'arrigo RD, Cook ER, Buckley BM (2001) Hydrometeorological reconstructions for northeastern Mongolia derived from tree rings: 1651-1995. J Clim 14:872-881

Qian W, Lin X (2004) Regional trends in recent temperature indices in China. Clim Res 27:119-134

Sano M, Furuta F, Sweda T (2009) Tree-ring-width chronology of Larix gmelinii as an indicator of changes in early summer temperature in east-central Kamchatka. J For Res 14:147-154

Shao XM, Wu XD (1997) Reconstruction of climate change on Changbai Mountain, Northeast China using tree-ring data. Chin Quat Sci 1:76-85 (in Chinese)

Shaver GR, Canadell J, Chapin FS III, Gurevitch J and others (2000) Global warming and terrestrial ecosystems: a conceptual framework for analysis. Bioscience 50:871-882

Solomina ON, Wiles G, Shiraiwa T, D'Arrigo RD (2007) Multiproxy records of climate variability for Kamchatka for the past 400 years. Clim Past 3:119-128

Sun GY, Yu SP, Wang HX (2007) Causes, south borderline and subareas of permafrost in Da Hinggan mountains and Xiao Hinggan mountains. Sci Geo Sin 27:68-74 (in Chinese)

Wang LL, Shao XM, Huang L, Liang EY (2005) Tree-ring characteristic of Larix gmelini and Pinus sylvestris var. mongolica and their response to climate in Mohe, China. Acta Phytoecol Sin 29:380-385 (in Chinese)

> Wigley TML, Briffa KR, Jones PD (1984) On the average value of correlated time series, with applications in dendroclimatology and hydrometeorology. J Clim Appl Meteorol 23: 201-213

Yang B, Bräuning A, Liu JJ, Davis ME, Shao YJ (2009) Temperature changes on the Tibetan Plateau during the past 600 years inferred from ice cores and tree rings. Global Planet Change 69:71-78

Yang Z, Ou-Yang H, Xu XL (2010) Effects of permafrost degradation on ecosystems. Acta Ecol Sin 30:33-39 (in Chinese)

Zhang QB, Cheng GD, Yao TD, Kang XC (2003) A 2, 326-year tree-ring record of climate variability on the northeastern Qinghai-Tibetan Plateau. Geophys Res Lett 30:1739-1741 
doi:10.1029/2003GL017425

Zhang XL, Cui MX, Ma YJ, Wu T, Chen ZJ, Ding WH (2010) Larix gmelinii tree-ring width chronology and its responses to climate change in Kuduer, Great Xing'an Mountains. Chin J Appl Ecol 21:2501-2507 (in Chinese)

Zhou M, Yu X, Feng L (2002) Analysis on the driving force of the permafrost degeneration in Daxinganling. J Arid Land Resour Environ 16:44-47 (in Chinese)

Editorial responsibility: Geir Ottersen, Oslo, Norway
Zhou M, Yu X, Feng F, Wang L, Na P (2003) Effects of permafrost and wetland in forests in Great Xingan Mountain on ecology and environment. J Beijing For Univ 25:91-93 (in Chinese)

Zhu HF, Fang XQ, Shao XM, Yin ZY (2009) Tree ring-based February-April temperature reconstruction for Changbai Mountain in Northeast China and its implication for East Asian winter monsoon. Clim Past 5:661-666

Submitted: October 4, 2010; Accepted: February 11, 2011 Proofs received from author(s): May 16, 2011 